\title{
Early Medieval Wales: material evidence and identity
}

\author{
Edwards, Nancy
}

\section{Studia Celtica}

DOI:

10.16922/SC.51.2

Published: 31/12/2017

Peer reviewed version

Cyswllt i'r cyhoeddiad / Link to publication

Dyfyniad o'r fersiwn a gyhoeddwyd / Citation for published version (APA):

Edwards, N. (2017). Early Medieval Wales: material evidence and identity. Studia Celtica, 51, 65-87. https://doi.org/10.16922/SC.51.2

\footnotetext{
Hawliau Cyffredinol / General rights

Copyright and moral rights for the publications made accessible in the public portal are retained by the authors and/or other copyright owners and it is a condition of accessing publications that users recognise and abide by the legal requirements associated with these rights.

- Users may download and print one copy of any publication from the public portal for the purpose of private study or research.

- You may not further distribute the material or use it for any profit-making activity or commercial gain

- You may freely distribute the URL identifying the publication in the public portal ?
}

Take down policy

If you believe that this document breaches copyright please contact us providing details, and we will remove access to the work immediately and investigate your claim. 


\section{EARLY MEDIEVAL WALES: MATERIAL EVIDENCE AND IDENTITY}

\section{NANCY EDWARDS ${ }^{1}$}

In our modern, rapidly changing world we have become increasingly aware of the complexities of identity ${ }^{2}$ and this interest is also reflected in how archaeologists study material remains. ${ }^{3}$ Over the last twenty years we have become increasingly critical of the term Celtic, ${ }^{4}$ other than in the linguistic sense, ${ }^{5}$ and we have also begun to use material evidence to explore the complexities of identity in the centuries after the ending of Roman Britain. For example, in England the study of furnished Anglo-Saxon graves is no longer seen almost entirely in terms of ethnicity and religion. Indeed, it is now generally accepted that many of those being buried were the indigenous British population who in dress and many of their accoutrements, as well as language, were taking on a new identity. ${ }^{6}$

There has also been a growing interest in changing identities in Wales in the period $c$. $\mathrm{AD} 400-1100^{7}$ but there has been comparatively little interrogation of the archaeological evidence for what this might reveal about them. This is largely because much of the material culture for this period in Wales, particularly settlements, has proved remarkably difficult to identify. Burials do not usually have any grave-goods, there is no native pottery and there are

\footnotetext{
${ }^{1}$ School of History and Archaeology, Bangor University.

${ }^{2}$ For an excellent analysis of the history of identity (both in relation to the self and collective identity) from the origins of the concept between the two World Wars to the present day, see Izenberg 2016, especially 1-24, 445-57. The deep public interest in the complexities of identity is clearly demonstrated by the BBC's invitation to Kwame Anthony Appiah to explore this topic in his 2016 Reith Lectures.

${ }^{3}$ Archaeological interest was inspired by the impact of identity on the social sciences in the 1980s and 1990s, particularly on anthropology and history, Izenberg 2016, 355, 386. For the important links between archaeology, politics, nationalism and identity, see Kane 2003. On the archaeology of identity in relationship to gender, age, ethnicity, status and religion, see Díaz-Andreu et al. 2005.

${ }^{4}$ The impact of the politics of identity and nationalism has led archaeologists to rethink the validity of the Celts as ancient peoples and their material remains as Celtic, see James 1999; Wells 2001; Collis 2003.

${ }^{5}$ On the usefulness of inscriptions with Celtic names and Celtic place-names in reconstructing ancient linguistic geography, see Sims-Williams 2012, 431, 437-42.

${ }^{6}$ In Hamerow, Hinton and Crawford 2011 a whole section is devoted to aspects of Anglo-Saxon identity; see especially Hills 2011. On Anglo-Saxon burials and identity, see Lucy 2000, 173-86.

${ }^{7}$ This has mainly been focused on the languages spoken and the emergence of a Welsh as opposed to a British identity was slow, Charles-Edwards 2013, 75. On changes in the terminology evident in the written sources, see Pryce 2001.
} 
few other diagnostic artefacts. Ornamental metalwork remains relatively scarce and often without context despite a steady trickle of new discoveries recorded by the Portable Antiquities Scheme. Therefore the most prolific type of archaeological evidence remains the early medieval inscribed stones and stone sculpture - over 570 monuments are now known and, mainly because of the languages and names in the inscriptions carved on these, they are also a major source of evidence on identity. ${ }^{8}$

Wales did not exist as a political entity during the early Middle Ages, though, by the end of the period, the ethnic and geographical concepts of 'Wales' and the 'Welsh' were both well established. ${ }^{9}$ Nevertheless, there were a complex series of overlapping identities within Wales which could evolve and be re-invented to serve new ends as the period progressed. Important to such identities is the geographical fragmentation of Wales with its mountainous central core leading to distinctive regional differences between, for example, the Irish Sea coasts, those which faced the Severn estuary and Bristol Channel and the emerging Marches. The major identities which continue, develop and evolve during the early Middle Ages are cultural and linguistic - British, Roman, Irish, Hiberno-Scandinavian, perhaps CambroNorse,${ }^{10}$ or Cambro-English in the Marches. Religious identity in the form of Christianity, which had Roman roots in Wales, is also of significance and is most visible in the growing power of the church and the Christianization of the landscape. At a regional level we can see the survival and/or re-emergence of tribal identities in the post-Roman period and the development of identities associated with kingdoms, for example, Gwynedd, Powys, Glywysing and Dyfed, and sub-kingdoms, such as Rhos. By the end of the period we also have more the local divisions of the cantref and the commote. There are likewise ties which

\footnotetext{
${ }^{8}$ Redknap and Lewis 2007; Edwards 2007; 2013. For specific consideration of the names in the inscriptions, see Sims-Williams 2002; 2003.

${ }^{9}$ Davies 1990, 88; Pryce 2001, 776-8.

${ }^{10}$ This term has been used in connection with the later ninth- and tenth-century structures and material culture of the settlement at Llanbedrgoch, Anglesey, see Redknap 2004a, 166-7.
} 
impinge on identities between people and those they paid render and other dues to, not just secular, but also Christian with the local saint and the mother church, for example St Brynach of Nevern. We can also hint at very local identities, such as the geographical distinctiveness of living in and farming a particular valley, and the bonds of family, kin and land holding.

Therefore the relationship between these overlapping and changing identities and the material culture of early medieval Wales is undoubtedly a complex one and my aim here is more limited. It is to focus on the three major cultural and linguistic identities in early medieval Wales in the pre-Viking period: British, Roman and Irish, and the complexities of these identities. I will do this by examining aspects of the archaeological evidence for what it may - or may not - be able to tell us about the visibility and expression of these identities and their survival and re-invention as the period progresses.

\section{British (and Welsh) Identities}

Early medieval written sources relevant to Wales, such as Gildas's mid-sixth century $D e$ Excidio Britanniae ('The Ruin of Britain') ${ }^{11}$ and the early ninth-century Historia Brittonum ('The History of the Britons'), ${ }^{12}$ as well as continuing use of the Latin terms Britones and Britanni for the 'Welsh' and Britannia for 'Wales' in Cambro-Latin texts until the early twelfth century, demonstrate a lasting sense of British identity despite the loss of territory to the English. ${ }^{13}$ However, when we begin to examine the archaeological evidence for this enduring mentalité it raises important questions which remain very difficult to answer. First, to what extent are we able to identify the changing early medieval material culture of British (and Welsh) identity as the period progresses? Second, to what extent are we dealing with the

\footnotetext{
11 Winterbottom 1978. De Excidio has most recently been dated to c.530 x 545, see Charles-Edwards 2013, 215-18.

12 Morris 1980. The Historia Brittonum was written in Gwynedd 829/830.

${ }^{13}$ Pryce 2001, 777-9 also indicates that in Welsh the term Cymry was commonly used for the Welsh and Wales by 1100 . It was similar in meaning to Britones and Britanni.
} 
longue durée, the inheritance of a later prehistoric past which continued to a greater or lesser extent throughout the Roman period and subsequently reasserted itself?

Let us begin with the fifth- to mid-seventh century inscribed memorial stones, almost all of which have commemorative Latin inscriptions indicating that they once marked the graves of the elite, though some also very likely functioned as lasting symbols of land ownership; a significant number also have Christian formulae. ${ }^{14}$ Amongst the examples with Welsh names is Gwytherin 1, Denbighshire, where the Latin inscription commemorates Vinnemagli fili Senemagli ('Vinnemaglus son of Senemaglus'). ${ }^{15}$ Nevertheless, as Patrick Sims-Williams has demonstrated, where the linguistics of the names can be securely identified, people with Welsh names are in the minority compared with those with Irish and Latin names. ${ }^{16}$ Indeed, it may be argued that people with Welsh names were less likely to have their identity expressed through the erection of inscribed memorial stones. This could be related to status but it may also help to account for the comparative lack of monuments in the eastern half of Wales. There is, however, an important change. From the seventh century onwards, the majority of names appearing in the Latin inscriptions on stone sculpture, which is associated predominantly with major ecclesiastical sites demonstrating elite patronage, are Welsh as, for example, the cross at Llantwit Major which was commissioned by Hywel ap Rhys, the later ninth-century king of Glywysing. ${ }^{17}$ Nevertheless, the status of Welsh as a language suitable for inscriptions remains exceptional since the only known example is the ninth-century cross-carved monument from Tywyn, Merioneth, which commemorates two women: Tengrui, wife of Addian, buried close to Bud and probably a fourth person Meirchiaw, and Cun, wife of Celyn, expressing grief at her loss. ${ }^{18}$

\footnotetext{
${ }^{14}$ For discussion of their functions and formulae, see Edwards 2007, 31-43; 2013, 44-57.

${ }^{15}$ Edwards 2013, D2.

${ }^{16}$ Sims-Williams 2002, 29-30.

17 Ibid., 20-2; Redknap and Lewis 2007, G63; Edwards 2015, 2.

18 For detailed discussion of the inscription, see Sims-Williams 2002, 6-9; Edwards 2013, MR25.
} 
Turning now to ornamental metalwork, penannular brooches have their origins as a type in the pre-Roman Iron Age but were revitalized in new forms towards the end of the Roman period. ${ }^{19}$ Rob Collins has recently interpreted the development of Types F and G penannular brooches as part of a move towards a specifically British dress fashion and identity which he associates with the transition from a late Roman frontier army to leaders and their war-bands during the fifth and sixth centuries. ${ }^{20}$ This is an attractive theory but the lack of precise contexts and dating in many cases makes a more detailed consideration difficult. Nevertheless, the distributions of Types F and G suggest that they emerge in the lower Severn valley extending into Wales and Somerset and therefore may represent an emerging regional British cultural identity. Type $\mathrm{G}$ in particular is also found in Anglo-Saxon burial contexts, where they might likewise indicate an expression of British cultural identity, though they might equally be considered the products of local exchange. ${ }^{21}$ The distribution of Type $\mathrm{G}$ brooches is now also represented in north-west Wales with two examples from Anglesey. The first, only recently excavated, was found on the right breast of a female in a long-cist grave in a cemetery near Llangefni (Fig. 1). It is of a characteristic type similar to an old find from Trevor Rocks, near Llangollen. ${ }^{22}$ The second is one of three artefacts from the late Iron Age and Roman settlement with later rubble spreads at Cefn Cwmwd, which together suggest post-Roman activity in the immediate vicinity of the site. ${ }^{23}$ The closest parallel is with a brooch from Goss Moor, Roche, Cornwall, but there is a further example from Meols on the Wirral (one of three), which may suggest that the Anglesey brooches were the result of coastal trade and exchange or, in the second case, perhaps local imitation. ${ }^{24}$

\footnotetext{
${ }^{19}$ For discussion of typology and terminology, see Fowler 1963; Dickinson 1982. Type F have zoomorphic terminals whilst Type $\mathrm{G}$ have faceted terminals with lozenge-shapes.

${ }^{20}$ Collins 2010, 68-73.

${ }^{21}$ Type F: Ó Floinn 2001, 2-4; Type G: Dickinson 1982, 51, fig. 1; Hines 2000, 94-5.

22 Pers. comm. Iwan Parry, Brython Archaeology; Dickinson 1982, Type G1.1, fig. 3, no. 27.

${ }^{23}$ Cuttler et al. 2012, 158-60, 295

${ }^{24}$ Dickinson 1982, Type G1.7, fig. 4, no. 15; Griffiths et al. 2007, 61, no. 301.
} 
More recently, Susan Youngs has identified a third type of penannular brooch dated to the sixth or seventh centuries found in Wales and the Marches which may likewise be indicative of a British cultural identity. Examples are characterized by spatulate terminals and sometimes stamped ornament: ${ }^{25}$ there are two almost plain, tinned bronze brooches from Pant-y-Saer and Ty'n y Coed, Anglesey (Fig. 2), ${ }^{26}$ while the stamped examples include those from Shavington, Cheshire, Much Dewchurch, Herefordshire and Kenfig, Glamorgan (Fig. 3). ${ }^{27}$ Furthermore, there are now increasing indications, as Mark Redknap has shown, that the fashion for penannular brooches as a badge of identity continued amongst the elite in Wales into the eighth and ninth centuries with more elaborate examples, as it also did with different regional forms in Ireland and Scotland. For example, the Newton Moor brooch found near Cowbridge Glamorgan, is an elaborated Type $\mathrm{G}$ decorated with poorly executed gold filigree and a blue glass bead ${ }^{28}$ while a recent Portable Antiquities Scheme discovery of a fragment from Llanarmon yn Iâl, Denbighshire, may be identified as a mount with similar ornament which was once part of a brooch with spatulate terminals (Fig. 4). ${ }^{29}$

In attempting to identify evidence for a British identity in the settlement archaeology we immediately face major problems because of the difficulty in locating sites, ${ }^{30}$ especially those which are not associated with elites, though things are gradually improving as a result of more accurate radiocarbon dating. Nevertheless, in thinking about British identity, several questions emerge which relate to regionality and the longue durée. In other words the continuation of late regional prehistoric settlement forms - hillforts, enclosed settlements and other hutgroups - through the Roman centuries and into the early medieval period and to

\footnotetext{
${ }^{25}$ Youngs 2007, 91-5, 98-101.

26 Phillips 1934, 18-20; Edwards 2008.

27 Youngs 2007, figs 4.6, 4.9. There has also been a recent Portable Antiquities Scheme discovery of a brooch with spatulate terminals from Tenby (NMGW 2016.43), pers. comm., Mark Lodwick.

${ }^{28}$ Redknap 1995, 60-2, pl.; 2007, 74, no. 27.

${ }^{29}$ Redknap, Portable Antiquities Scheme, NMGW-3E31B4.

${ }^{30}$ For discussion of the problems of identifying early medieval settlement sites in western Britain more generally, see Blair 2013.
} 
what extent these may be relevant to expressions of British identity and its reinvention in the post-Roman period.

I will take the north-west as a brief example. Kate Waddington has recently emphasized the significance of the longue durée seen in settlement types in north-west Wales from the late prehistoric through to the beginning of early medieval period, though more subtle changes are also evident over time. ${ }^{31}$ It may be seen, for example, in the continued occupation or activity in - since a significant number have Roman finds - or reoccupation of hillforts. Dinas Emrys in the Nant Gwynant Valley in Snowdonia, is a major example of this. The post-Roman occupation was identified because of the presence of imported pottery from the eastern Mediterranean and south-west Gaul. ${ }^{32}$ This is also almost certainly the site which, by the early ninth century, had acquired an important mythical status as indicated by the tale of Ambrosius in the Historia Brittonum. ${ }^{33}$ The continuing strategic and symbolic significance of the hillfort at Degannwy, the name of which, arx Decantorum, would seem to recall a people known as the Decanti, is also clear at this time from two references in the Annales Cambriae.$^{34}$ However, the continuation of activity at some other larger hillforts where there is extensive Roman activity, such as Tre'r Ceiri and Dinorben, is currently very difficult indeed to substantiate. ${ }^{35}$ Indeed, it seems likely that the evidence we currently have of early medieval occupation on comparatively small hillforts in Wales, such as Dinas Powys ${ }^{36}$ and Dinas Emrys, rather than their larger counterparts, is indicative of a change in society and function, from places of tribal and community significance to the strongholds of leaders who emerged in the period of post-Roman kingdom formation. We might expect more continuity

\footnotetext{
${ }^{31}$ Waddington 2013, 88-9, 117.

32 Savory 1960; Edwards and Lane 1988, 55-7; Waddington 2013, 211-13; Campbell 2007, 11, 19-20, 27, 29, 87.

${ }^{33}$ Morris 1980, chs 40-2.

${ }^{34}$ Edwards and Lane 1988, 50-3; Waddington 2013, 128-9; Morris 1980, 47-8, 88-9.

35 Waddington 2013, 220-3; Gardner and Savory 1964, 1971; Edwards and Lane 1988, 64-6.

${ }^{36}$ Alcock 1963; 1987, 7-150; Seaman 2013.
} 
in the dwellings of lower status farming communities. Some hutgroups, such as Tŷ Mawr, Holyhead, have a very long period of occupation and reoccupation which radiocarbon dates have demonstrated stretches into the fifth and sixth centuries AD ${ }^{37}$ However, it may be suggested that at this level potentially important changes in settlement form and society may have occured during the seventh and eighth centuries. For example, recent geophysics and exploratory excavations at Rhuddgaer in south-west Anglesey revealed a substantial, subrectangular stone-footed building, one of several making up a nucleated farming settlement, with associated fields. Radiocarbon dates indicate that the building is most likely to have been occupied during the seventh and eighth centuries. ${ }^{38}$ This settlement might be a tref, a term found in the Llandaf charters, which refers to one or more farmhouses together with their associated land. ${ }^{39}$

\section{Roman Identities}

The extent to which aspects of Roman identity continued into the post-Roman period and how these evolved and were reinvented over time and are manifested in terms of material evidence are complex issues. Indeed, an essential aspect of this is the continuity of Christianity from the Roman period onwards rather than, as was once thought, its reintroduction from Gaul during the later fifth century. ${ }^{40}$

Firstly, if we return to the fifth- to seventh-century inscribed memorial stones, Thomas Charles-Edwards has argued that the Latin on these is indicative of its survival as a spoken language until around 700 and, of course, this has clear implications for the continuation of aspects of Roman identity. ${ }^{41} \mathrm{We}$ can also see the continuing use of Latin

\footnotetext{
37 Smith 1985; 1987, 25; Edwards and Lane 1988, 118-20; Waddington 2013, 158-60.

${ }^{38}$ Hopewell and Edwards in press.

${ }^{39}$ Charles-Edwards 2013, 285.

${ }^{40}$ For the view that Christianity was reintroduced into Wales, see Nash-Williams 1950, 1, 55. This was finally overturned in Thomas 1981; for historiographical discussion, see Edwards 2016a, 98-9.

${ }^{41}$ Charles-Edwards 1995, 718-19; 2013, 114.
} 
names and occasionally titles on these monuments, which, interestingly, are concentrated in parts of Wales where there is comparatively little evidence of earlier romanitas. For example, a later fifth- or early sixth-century inscribed stone from Newchurch, Carmarthenshire, commemorates Severinus son of Severus ${ }^{42}$ while that from Llandanwg, Merioneth, which also has the Christian hic iacit formula and is probably datable to the second half of the sixth century, commemorates Gerontius, son of Spectatus, ${ }^{43}$ all common Latin names.

Nevertheless, the survival of Roman identities was certainly much more complex than this. To take two well-known examples: firstly, the Latin and Primitive Old Irish ogam inscribed stone from Castell Dwyran, Carmarthenshire. The Christian Latin inscription reads Memoria Voteporigis Protictoris ('The memorial or tomb of Voteporix the Protector'). The name of the man commemorated is Irish, though, as Patrick Sims-Williams has demonstrated, he cannot be identified as one of the tyrants mentioned by Gildas, as was once thought, and the monument probably dates somewhat earlier to the late fifth or earlier sixth century. ${ }^{44}$ Nevertheless, his title, protictor, originally referred to a member of the Roman bodyguard. Was this a hereditary title with its origins in the Roman past and if so, did it have any meaning other than an honorific which might suggest the survival of some vestige of Roman authority? Or had it been resurrected by the man commemorated alongside his Irish and Christian identities as a means of providing legitimacy to a new elite? Secondly, the Latin inscribed stone from Ffestiniog, Merioneth, reads Cantiori hic iacit Venedotis cive fvit [c]onsobrino Ma[g]li magistrati, 'Cantiorix (or Of Cantiorius), here he lies, he was a citizen of Gwynedd, cousin of Maglus the magistrate'. It is probably datable to the first half of the sixth century. Again, the hic iacit formula suggests the man commemorated was a Christian and the two personal names are Brittonic, but the terms civis ('citizen') and magistratus

\footnotetext{
42 Severini fili Severi, Edwards 2007, CM36.

${ }^{43}$ Geronti hic iacit fili Spectati, Edwards 2013, MR12.

${ }^{44}$ The ogam inscription on the same stone is confined to the personal name Votecorigas, Edwards 2007, CM3; see also Sims-Williams 1990, 226.
} 
('magistrate/office holder') are clearly Roman. The fact that a citizen of Gwynedd is being commemorated is particularly significant since this is the earliest mention of the early medieval Welsh kingdom. However, it is much more difficult to determine what cive, which doubtless recalls the status of Roman citizenship, and magistratus actually meant a century or more after the ending of Roman rule. Again, should we be thinking in terms of hereditary use or their adoption by the emergent elite of Gwynedd as conscious identifiers with the Roman past ${ }^{45}$

The original location of the Cantiorix stone is also of interest. It came from the site known as Beddau Gwŷr Ardudwy ('The Graves of the Men of Ardudwy') situated beside the Roman road running north from the fort at Tomen-y-Mur. As such it is one of a significant number of early inscribed stones, mainly in the north-west and the uplands of Glamorgan but also including that from Castell Dwyran, which were originally set up in prominent locations near Roman roads and sometimes also in the vicinity of Roman forts, suggesting the continuing importance of these places in the landscape. ${ }^{46}$ Such a location would seem to be prolonging an aspect of Roman identity through the practice of Roman roadside burial and in most instances the formulae used also suggest that those commemorated were Christian. However, the situation is more complicated in the case of Beddau Gwŷr Ardudwy because the place-name refers to prehistoric burial cairns destroyed during the nineteenth century, and as such this is an important example of the reuse of such sites, a characteristic widely found in Britain and Ireland in the post-Roman period. In so doing prehistoric remains, which had become part of a localized mythical landscape, were seen as the graves of heroic 'ancestors', and were also being reinvented as part of an early medieval identity and harnessed to serve this new purpose.

\footnotetext{
45 Edwards 2013, MR8.

${ }^{46}$ Fox 1939; Edwards 2013, 46-7.
} 
The strong link between continuing Roman identity and Christianity, which was in touch with developments on the Continent, can also be seen in a small group of extended Latin inscriptions found mainly in north-west Wales. ${ }^{47}$ For example, that from Trawsfynydd, Merioneth, was originally located beside a route-way which probably follows the line of a Roman road and was also set up close to a prehistoric standing stone. It commemorates Porivs hic in tvmvlo iacit homo [x]p(ist)ianvs fvit ('Porius lies here in the tomb, he was a Christian man'), thereby drawing attention to his Christian identity. ${ }^{48}$ Secondly, the stone from Llantrisant, Anglesey, probably datable to the second half of the sixth century, has the longest Latin inscription surviving on any of these monuments. ${ }^{49}$ It commemorates the wife of Bivatisus but most of the inscription is about her husband. It begins by recording his clerical status and background. He was $f[a] m u[l u] s d(e)$ i sacerdos et vasso Paulini ('a servant of God, priest and disciple of Paulinus'). In Britain this is the only example of the formula famulus dei ('servant of God'), a term of humility common on sixth-century epitaphs in southern Spain and in the Rhône valley. ${ }^{50}$ It usually, but not always, refers to those who followed a monastic life and the term sacerdos is now identified as a reference to priestly office rather than necessarily a bishop. ${ }^{51}$ Vasso ('disciple') might also refer to a monk and is otherwise found in Gaul and Spain. ${ }^{52}$ The final part of the inscription praises his virtues: 'and of all citizens and kinsfolk an example and in (his) character of(?) discipline and of wisdom as gold in stones' or '(better than) gold and precious stones'. Here the reference is to

\footnotetext{
47 Ibid., 55-6.

48 Ibid., MR23.

49 Ibid., AN46. The full inscription reads: ...iva (or ... ina) / sanctissi/ma mvlier / [h]ic iacit qve / fvit amati/[s?]si(ma) co[n]ivx Bi/vatisi f[a]mv[lv]s / d(e)i sacerdos et vas/so Pavlini Avdo (or Ando) cog/na[tion]e et omni/vm civivm adqvae / parentvm exempl/a et moribvs dis/ciplina ac sapien/tiae // Avro e[t] / lapidibv/s ("...iva (or ...ina), a most holy woman, here she lies, who was the most loving wife of Bivatisus, servant of God, priest and disciple of Paulinus, from Avdus (or Andus) by kindred, and of all citizens and kinsfolk an example and in (his) character of(?) discipline and of wisdom as gold in stones' or '(better than) gold and precious stones').

50 Longley 2012, 414, fig. 5.

51 Nash-Williams 1950, no. 33; Thomas 2010; Edwards 2013, 214.

52 Ibid.
} 
Christian citizens and the phraseology would be appropriate to a cleric and to the monastic life; the reference to gold and precious stones is echoed in passages in the Old Testament. ${ }^{53}$ Furthermore, as Patrick Sims-Williams has shown, the inscription echoes the structure of a Latin panegyric, the tradition of which may have survived in Britain into the sixth century or been reintroduced from Gaul where it continued to flourish. ${ }^{54}$

Turning, now, to south-east Wales, the comparative lack of early inscribed stones compared with the west leads one to think that there was little need to express a continuing Roman or a Christian identity in this way. Nevertheless, the much more visible Roman imprint on the landscape in the form of the legionary fortress at Caerleon, the town of Caerwent and the villas, notably the impressive remains at Cae'r Mead, Llantwit Major, ${ }^{55}$ would lead us to suspect that some aspects of Roman identity remained stronger in this part of Wales than elsewhere, at least amongst some elements of the population. However, the historical barrier of AD 410 for the ending of Roman Britain has too often resulted in insufficient attention being paid to the process and pace of change across the fourth and fifth centuries and the related degrees of continuity. ${ }^{56}$ Indeed, the problem of to what extent Roman settlements in south-east Wales were abandoned from the mid-fourth century as suggested by the demise of Roman coins and ceramics, ${ }^{57}$ remains a pressing one since radiocarbon dating is still so seldom applied, and means that sequences of abandonment or continuity and reoccupation are still very far from being understood. For example, at Sudbrook Road, Portskewett, there were indications of Roman high-status occupation nearby. However, it was assumed that the site was abandoned in the mid-fourth century when the

\footnotetext{
53 Ibid., 215.

54 Ibid.; Sims-Williams 1984, 170-1.

55 Nash-Williams 1953; Hogg 1974. Graves in the cemetery overlying the villa have been radiocarbon dated to the seventh to tenth century, see Redknap and Lewis 2007, 575.

${ }^{56}$ For a recent reassessment of the archaeology of the fourth and fifth centuries for Britain as a whole, see Gerrard 2013.

${ }^{57}$ A view long reiterated, e.g. Webster 1984, 300; Brewer 2004, 237.
} 
coin sequence ends, even though late Roman, shell-tempered ware was recovered from an earth and rubble bank later covered in colluvium with a burial radiocarbon dated to the seventh or eighth centuries AD above. ${ }^{58}$ There were, however, no other radiocarbon dates which might have helped to establish the chronology more precisely.

The town of Venta Silurum (Caerwent) gave its name to the early medieval kingdom of Gwent and the scale of the walls today testify to the continuing impact of the Roman remains on the landscape during the early Middle Ages. Jeremy Knight has studied a sequence of metal artefacts which suggest activity in Caerwent throughout the early medieval period. ${ }^{59}$ However, the significance of these in terms of the level of continuing or renewed occupation and its significance for the longer-term preservation of elements of a Roman identity is very difficult to gauge as the excavations were mainly conducted in the early twentieth century. Ray Howell has also brought to our attention the extent to which parts of the legionary fortress at Isca (Caerleon), for example the Roman triumphal arch located in the centre of the fort, were likewise still upstanding during the early medieval period and the impact such overt symbols of romanitas may have continued to have. ${ }^{60}$ There is also an increasing body of evidence for early medieval activity on a number of sites within the fort, most recently at Priory Fields where unmortared walls provisionally dated to the fifth and sixth centuries have been found adjacent to and overlying a Roman warehouse. ${ }^{61}$ Overall, the evidence seems to be indicative of at least intermittent occupation on some scale within the fort and its environs and this undoubtedly has implications for how those concerned may have viewed themselves and the Roman inheritance, in the midst of which they lived.

\footnotetext{
${ }^{58}$ Brett et al. 2015.

${ }^{59}$ Knight 1996.

${ }^{60}$ Howell 2012.

${ }^{61}$ Gardner and Guest 2011, 2, 11-12, 20-2. I am grateful to Peter Guest for giving me access to the assessment report prior to the completion of post-excavation analysis of the site.
} 
Robin Fleming has rightly identified the importance of the recycling of Roman metalwork and other materials in the post-Roman period. ${ }^{62}$ Nevertheless, a further difficulty is how long some Roman artefacts may have remained in use and, as Ellen Swift has recently emphasized, the extent to which they were curated, repaired and modified to take on new functions and meanings which may have important implications for changing cultural identities. ${ }^{63}$ The appearance of Roman heirlooms and other objets trouvés in Anglo-Saxon graves is well known ${ }^{64}$ but little attention has been paid to the reuse of Roman artefacts in early medieval Wales. In the cemetery at Llandough, for example, probable Roman glass beads were still worn by some of those buried and together with Roman coins may have been deposited as amulets; it has also been suggested that a first-century Roman brooch had been reused to secure a shroud. ${ }^{65}$ Similarly, in the intra-mural cemetery at Caerwent the grave of a woman, which contained a late Roman bracelet and coin $c .335-48$, was radiocarbon dated to cal. AD540-770. ${ }^{66}$ Roman pottery sherds, some reworked as spindle whorls, have also been found in early medieval contexts on high-status hillforts, such as Dinas Powys and Britton Ferry, presumably recycled from Roman sites in the vicinity. ${ }^{67}$ At the same time it is well known that imported pottery, including eastern Mediterranean amphorae containing wine and olive oil, and luxury red-slipped tableware were also reaching sites, such as Dinas Powys and Britton Ferry, in the later fifth and first half of the sixth centuries. ${ }^{68}$ It seems sensible to see this phenomenon, not only in terms of long-distance, luxury trade, but also as an indication of the continuing emulation of Roman elite lifestyles in food and drink. Even at the royal crannog at Llan-gors occupied in the late ninth early tenth century there were possible

\footnotetext{
62 Fleming 2012.

${ }^{63}$ Swift 2012.

${ }^{64}$ E.g. Meaney 1981, 222-31; White 1988, 159-66.

65 Holbrook and Thomas 2005, 32-5, 34, 67, figs 14D, 34.1.

${ }^{66}$ Farley 1984, 229; Howell 2004, 256.

${ }^{67}$ Alcock 1963, 148-9, nos 1-3, fig. 33; Campbell 1991, appendix 6; Wilkinson 1995, 17.

${ }^{68}$ Alcock 1963, 125-39; Wilkinson 1995, 17-18; Campbell 2007, passim.
} 
spindle-whorls and a gaming piece fashioned from Roman pottery as well as an unstratified Roman black glass counter. ${ }^{69}$

Another way, however, to think about the continuation of a Roman identity and its reinvention to serve new ends is in the growing power of the church which, once spoken Latin ceased more generally, continued as the language of liturgy and learning. Like York and Canterbury, for example, there is good evidence to suggest that the Roman town of Caerwent was reinvented as a monastic centre, first mentioned in Asser's later ninth-century Life of King Alfred, ${ }^{70}$ the foundation of which is later attributed to the Irish saint Tatheus. ${ }^{71}$ The archaeological evidence also hints at continuity of Christianity in Caerwent from the Roman period onwards. It begins with the well known pewter bowl scratched with a chi-R graffito, possibly part of a late Roman agape set. ${ }^{72}$ Early medieval radiocarbon dates from graves in the Eastgate cemetery confirm extra-mural burial in the Roman fashion and suggest a floruit in the sixth and seventh centuries, by which time they are presumably Christian. However, the large intra-mural cemetery in the vicinity of the parish church suggests a gradual shift in focus during the seventh and eighth centuries to a monastic setting. ${ }^{73}$ There is also a cross-head dated to the tenth or eleventh centuries. ${ }^{74}$ A similar trajectory is also possible at Caerleon, the location of the martyrdoms of Julius and Aaron mentioned by Gildas. $^{75}$

\section{Irish Identities}

\footnotetext{
${ }^{69} \mathrm{NMW} 2004.56 \mathrm{H}$ no 8407; 91.5H/2.56; 91.4H/2.12; 93.13H/7.2. I am grateful to Mark Redknap and Sian Iles at National Museum Wales for the opportunity to examine these artefacts.

70 Keynes and Lapidge 1983, 56-7, ch. 79.

${ }^{71}$ Wade-Evans 1944, chs 6 and 9, 274-7; Knight 1970-1, 35 suggests the life was written in the mid-twelfth century.

72 Boon 1992, 17-18, fig. 2.

73 Campbell and Macdonald 1993, 87-8, 90; Farley 1984, 229-30.

${ }^{74}$ Redknap and Lewis 2007, MN2.

75 Winterbottom 1978, ch. 10; Seaman 2015; Howell 2012, 13-14; Redknap and Lewis 2007, MN1.
} 
In assessing the significance of Irish identities in post-Roman Wales, it is important to view the Irish Sea as a route-way rather than a barrier. ${ }^{76}$ After the Romans and prior to the Viking Age, we have to imagine a major form of transport as sea-going hide currachs, which would certainly have been able to make the crossing in good weather. ${ }^{77}$ Furthermore, although not presently as precise as we might like, movement of people across the Irish Sea in the postRoman period can now be suggested scientifically as a result of Oxygen Strontium isotope analysis of human teeth from burials in cemeteries in Wales, Ireland and the Isle of Man. For example, analysis of burials from three pre-Viking Age cemeteries in the Isle of Man, which occupies a key position in the Irish Sea, has indicated that some individuals may have spent their early childhood years in coastal areas of England, Scotland, Ireland and Wales. ${ }^{78}$

The early inscribed stones, especially those with ogams, are still the most significant evidence we have for analysing the nature and extent of Irish settlement, integration and changing identities as well as enabling us to chart the gradual demise of spoken Irish by around AD600. As already noted, the fact that the main distributions of the inscribed stones are in north-west and south-west Wales suggests that they were a direct product of this period of upheaval, settlement and integration, which resulted in the need to proclaim and preserve the identities of those commemorated and demonstrate claims to the land, whether longstanding or newly acquired.

The greatest concentration of inscribed stones demonstrating evidence of Irish settlement and identity is in the south-west. Of the sixty-five inscribed stones from Pembrokeshire, Carmarthenshire and Ceredigion, five are ogam only; seventeen are in the

\footnotetext{
${ }^{76}$ The important concept of an Irish Sea zone (sometimes misleadingly termed a 'culture province') and open to the Atlantic seaways was first articulated by Fox 1943, 28-44; see also Moore 1970; Cunliffe 2001.

77 McGrail 1998, 173-91; MacCarthaigh 2008; Severin 1978 for an example of a long-distance modern voyage; pers. comm., Darina Tully. It is unclear to what extent and how long the use of 'Romano-Celtic' plank-built sailing boats, e.g. that from Barland's Farm, Caldicot, continued beyond the Roman period, see Nayling and McGrail 2004.

78 Hemer et al. 2014.
} 
ogam and roman alphabets, implying the recognition of more than one linguistic audience, while the remaining forty-three are in the roman alphabet only. ${ }^{79}$ Many commemorate people with Irish names, use the $\mathrm{X}$ fili $\mathrm{Y}$ (' $\mathrm{X}$ son of $\mathrm{Y}$ ') formula and roman inscriptions are often vertical, all features regarded as characteristic of Irish-influenced inscriptions. I will take three examples which shed light on changing identities. First, the monument from Bridell in north-east Pembrokeshire is one of a small number of ogam-only inscribed stones. The inscription reads Nettasagri maqi mucoi Briaci ('of Nettasagri son of the kindred of Briaci'). As Patrick Sims-Williams has shown, the first name is Irish, the second probably so and this is the only example in Wales of the maqi mucoi formula, commonly found in Ireland. Since the inscription is in ogam only, it is almost certainly early in the series. ${ }^{80}$ Secondly, the bilingual inscription on the stone at St Dogmaels nearby uses the ' $\mathrm{X}$ son of $\mathrm{Y}$ ' formula for both inscriptions and the reads in Latin Sagrani fili Cvnotami, in ogam Sagragni maqi

Cunatami. The names suggest a process of integration is in train since, interestingly, as Patrick Sims-Williams has shown, the patronym, Cvnotami, is a British name but his son's name is Irish. ${ }^{81}$ Thirdly, the inscribed stone at Penbryn in southern Ceredigion is in roman letters only and reads Corbalengi iacit / Ordovs ('Here lies Corbalengus, an Ordovician'). The identity being conveyed on this monument is both complex and intriguing since the name of the man commemorated is Irish, the hic iacit formula identifies him as a Christian and he is also a member of the Ordovices, a tribal identifier associated with mid to north Wales which has its origins in the pre-Roman past. Furthermore, the stone is sited on an earlier cairn which may have contained a Roman cremation. In this way another conscious link was being made with the past. ${ }^{82}$

\footnotetext{
79 Edwards 2007, 31.

80 lbid., P5.

81 Ibid., P110.

82 Ibid., CD28.
} 
There has been a tendency to underplay the impact of Irish settlement and cultural identity on north Wales since there are only three known stones with ogam inscriptions, all bilingual. ${ }^{83}$ Nevertheless, of the fourteen inscribed stones in Anglesey, there is one bilingual, and four or five with Irish names, all located in the north-western half of the island. Three of these also have a Christian identity demonstrated by the use of the hic iacit formula. ${ }^{84}$ Llanfaelog 1, probably a reused prehistoric standing stone, is a rare example of a monument still in situ. The Christian Latin inscription reads Cvnogvsi hic iacit ('of Cunogusus, here he lies'), a man with an Irish name. Similarly, Patrick Sims-Williams has shown that the Irish name of the man on the bilingual stone, Llanfaelog 2, Mailisi in the roman script, Ma[ili]su in ogam, means 'The Bald One of Jesus', probably indicating he was a monk. The monument probably dates to the early to mid-sixth century suggesting the likely beginnings of monasticism on the island at this time. The name also survives in the local church dedication to St Maelog, thereby indicating the development of a local saint's cult associated with the man commemorated, and he appears as a disciple in the Life of St Cybi c. 1200 as well. ${ }^{85}$

It is also relevant to mention the fragmentary lead coffin from Rhuddgaer in southwest Anglesey. Both the lead coffin with its plaster lining and the context in which it was found with Roman artefacts suggest a Roman-type burial and a Roman Christian identity. However, both long sides have a mirror-image inscription reinterpreted by Patrick SimsWilliams to read Camvloris hoi, meaning 'Camuloris here'. The name is British but hoi is a unique roman-letter spelling of the Primitive Old Irish xoi found on ogam stones in Ireland where it has been interpreted as the equivalent of the Christian hic iacit formula. ${ }^{86}$ It may be fourth or early fifth century and both the Roman form of burial and its closeness to the fort of

\footnotetext{
83 Edwards 2013: Llanfaelog 2 (AN13), Dolbenmaen 2 (CN18) and Clocaenog 1 (D1).

${ }^{84}$ In addition to AN13, the others are Bodedern 1, Llanbabo 1(?), Llanfaelog 1, Penrhosllugwy 1, see Edwards 2013, AN1, AN9, AN12, AN58. The last three have the hic iacit formula.

85 Ibid., AN13; Wade-Evans 1944, chs 5 and 10, 236-9.

${ }^{86}$ Edwards 2016b, 183-5, fig. 7.4; Sims-Williams 2003, 27; Swift 1997, 97-111.
} 
Segontium (Caernarfon) could denote a military connection with an Irish presence in the garrison.

The final cluster of inscribed stones indicating Irish settlement and identity is centred on the later kingdom of Brycheiniog in the south-east and consists of two ogam only and five bilingual inscribed stones, three of which are from Llywel, located between Llandovery and Sennybridge ${ }^{87}$ One of these commemorates Maccvtreni Salicidvni in Latin, Maqitreni

Saliciduni in ogam. The first name is Irish, and Patrick Sims-Williams has argued that the second might be a British place-name meaning 'Willow Fort', a site associated with the deceased, ${ }^{88}$ but, unfortunately, we have no idea where this might have been. A second monument is lost and the ogam reading unknown but the Latin inscription may read Canntiani et pa[t]er illius Maccvtreni hic iac[ivnt] ('of Canntianus and his father Maccutreni, they lie here'). ${ }^{89}$ Canntianus is a British name indicative of integration but the father's is the same as that on the previous stone, possibly denoting the same man (though he cannot have been buried in more than one place), but more likely another member of the same elite family with Irish roots in this small area. The last commemorates Taricor(o or $\boldsymbol{a})$ and, interestingly, the ogams partially overlie the earlier Latin inscription. ${ }^{90}$

Therefore the early inscribed stones provide important evidence of Irish settlement and the more complex identities associated with it. However, we face major problems when we attempt to go on to examine other types of archaeological evidence for continuing Irish identities in early medieval Wales. Firstly, early medieval cemeteries in Wales which include long-cists and cist-and-lintel graves are most commonly found in the north-west and southwest, but they are also part of a wider Irish Sea phenomenon since they are also

\footnotetext{
${ }^{87}$ Redknap and Lewis 2007: ogam only - Llanddeti (Ystrad) 1 (B11), Ystradfellte (Pen-y-Mynydd) 1 (B51); bilingual - Crickhowell 1 (B2), Llywel (Crai) 1 (B41) (lost), Llywel (Pentre Poeth) 1 (B42) and Trallwng 1 (B45); on Llywel (Aberhydfer) 1 (B40) the ogam and roman inscriptions are independent of each other. 88 Ibid., B42.

89 Ibid., B41. The reading is dependent on a sketch by Edward Lhuyd.

90 Ibid., B40.
} 
characteristically found in Scotland and south-west Britain, as well as in Ireland and the Isle of Man. In Anglesey, however, there are perhaps some indications of Irish settlement and identity in the cemetery evidence in the north-west of the island, in addition to the distribution of Irish-influenced early inscribed stones, as well as of possibly separate native communities further south. For example, the cemetery at Tŷ Mawr, Holyhead, ${ }^{91}$ which comprises mainly long-cists, is focused on a late Neolithic or early Bronze Age ring-ditch thereby harnessing the power of place and heroic associations with which these prehistoric funerary monuments were imbued. Secondly, at Arfryn, Bodedern, a Middle Bronze Age banked and ditched enclosed homestead, which would still have been visible as earthworks and was probably mistaken for a funerary monument, was likewise reused for early medieval burial with over 100 graves. These included long-cist graves but also a roman-letter inscribed stone commemorating Ercagni, a man with an Irish name, which may originally have been sited in the centre of the earlier earthwork, possibly marking the founder's grave. ${ }^{92}$ In both instances it might be argued that these sites were chosen for reuse because, as in Ireland, they resembled earlier ancestral burial monuments known in Tirechán’s seventh-century work on St Patrick as ferta. ${ }^{93}$ It may be suggested that the reuse of monuments resembling ferta at Ty Mawr and Arfryn, as well as the inscribed stone, may be indicative of an Irish connection and identity and suggests that a claim was being made to the surrounding land. The evidence here may be contrasted with that from the new cemetery excavation with long-cist graves I have already mentioned at Llangefni where the woman was found with a Type G1 penannular brooch, possibly indicative of a British identity, and there was also an unstratified Roman brooch from the site. Similarly, square-ditched mortuary enclosures seem to have their

\footnotetext{
${ }^{91}$ Cuttler et al. 2012, 104-21.

92 Hedges 2016; Edwards 2013, AN1.

93 Bieler 1979, 144-5; see also O’Brien and Bhreathnach 2011.
} 
origins in the late Roman world, ${ }^{94}$ but are now known from an increasing number of early medieval sites in north Wales, most recently cemeteries excavated outside the Roman fort at Segontium and at Llaniestyn in south-east Anglesey. ${ }^{95}$ However, these do not seem to be features found in Ireland and are therefore not suggestive of an Irish identity.

Continuing Christian contacts across the Irish Sea may be seen as a further aspect of the expansion of monasticism and the increasing power of the church. It would be naïve to see this, as E. G. Bowen did, purely in terms of the movements of saints, ${ }^{96}$ but there was certainly a two-way traffic. Archaeologically we can see it most notably in the distribution of usually anonymous, cross-carved grave-markers from $c .600$ onwards which were probably introduced from Merovingian Gaul along the western seaways since they are found throughout the Irish Sea region. In Wales they are again concentrated in the south-west and to a lesser extent the north-west suggesting the continuation of Irish Sea contacts. ${ }^{97}$ More specific is the late eighth- or earlier ninth-century cross-inscribed stone from Llanllŷr, Ceredigion, from the site of a later Cistercian nunnery, thereby suggesting the existence of an earlier foundation in the same place. The Latin inscription records a donation of land to Madomnuac, an Irish name, possibly referring to the Irish saint, St Modhomnóg of Ossory. ${ }^{98}$ It has to be said that as far as we know the scale of monastic sites in Wales and the comparative lack of evidence for material wealth apart from land are very different from Ireland. Nevertheless, the fashion for secondary relics in the form of bells, as well as croziers and books, is also found throughout the Irish Sea region, as well as in Brittany, and is an expression of that identity. ${ }^{99}$ Bells were very common in Ireland and Tim Young has

\footnotetext{
${ }^{94}$ Longley 2009, 113-15; there are late Roman examples at Lankhills, Winchester, Clarke 1999, 424-33, fig. 20, and Poundbury, Farwell and Molleson 1993, 49-51, 146-51, 233-9.

95 Kenney and Parry 2012, 261-70; Evans et al. 2016, 14-16, figs 2-5.

${ }^{96}$ Bowen 1954, 87-103; 1977.

97 Edwards 2007, 49, 56-60, 114-17; 2013, 70, 79-81.

98 The inscription reads: Tesquitus Ditoc / Aon filius Asa / Itgen dedit ('The small deserted place of Ditoc (which) Aon son of Asa Itgen gave to Madomnuac'), Edwards 2007, CD20.

${ }^{99}$ For a review of the evidence, see Edwards 2002, 252-64.
} 
identified evidence for making brazed iron bells both at Clonfad, Co. Westmeath, at the end of the seventh century, and at Armagh. ${ }^{100}$ There is a maximum of seven surviving bells in Wales and two from west Herefordshire (5 bronze, 4 iron). ${ }^{101}$ Hand-bells were also common in Roman Britain ${ }^{102}$ but, frustratingly, we do not know whether the Welsh bells were made locally using local skills or technology imported from Ireland or whether they were acquired from there as ecclesiastical gifts or in trade.

This brings us back to ornamental metalwork more generally. ${ }^{103}$ In Wales there has been a long-running tendency to see certain specific, mainly ornamental metalwork artefacts other than penannular brooches as stylistically Irish - or indeed Anglo-Saxon. This has sometimes led to the supposition that very little ornamental metalwork was being produced in early medieval Wales at all and that what we are seeing is necessarily the product of trade and exchange rather than local manufacture. This has resulted too often in the premise that objects which look stylistically Irish were necessarily made in Ireland or by someone from Ireland. A classic example of this is the Dinas Powys Type F penannular brooch lead die fragment (Fig. 5), which, in the 1960s, Leslie Alcock identified as the product of an Irish ornamental metalworker and therefore as evidence for Irish settlement, though he did acknowledge that such brooches had their origins in Roman Britain. ${ }^{104}$ More recently, Mark Redknap has rightly questioned the Irish connection on the grounds that, as we have seen, there are other Type F enamelled brooches from the Severn estuary region, suggesting a regional elite British identity, not an Irish one. ${ }^{105}$ Rather, penannular brooches of this type were introduced from there into Ireland where they become associated with a characteristic

\footnotetext{
100 Stevens 2010, 93-8; pers. comm. Tim Young.

${ }^{101}$ Fisher 1926; Edwards 2002, 256; Bourke 2008, 26.

102 Ibid., 22.

${ }^{103}$ For the most recent review of the corpus of early medieval ornamental metalwork in Wales, see Redknap 2007, 29-86.

104 Alcock 1963, 56-60.

105 The best parallel is from Stowe Green, near St Briavels, Glos., Redknap 2007, 30-2, 45-9, pl. V.
} 
Irish identity. ${ }^{106}$ A recent discovery from south-west Anglesey is a fragment of a probable boss decorated with bands of spirals and complex animal ornament and Mark Redknap has described the decoration as 'typical of fine Irish metalwork of the eighth or early ninth century' (Fig. 6). ${ }^{107}$ While this is true, do we necessarily need to regard this object as an Irish import? We could equally be seeing Anglesey as part of the wider Irish Sea zone with its resulting influence on cultural identity.

Turning, finally, to settlements, it is certainly not possible to identify the dwellings of Irish settlers in post-Roman Wales, even in the south-west, where the majority of ogam stones are found. Nevertheless, detailed investigation of the broader landscape contexts of stones with ogam inscriptions might be productive. For example, two monuments from Brawdy, Pembrokeshire, were found close to a multivallate earthwork enclosure tentatively identified as a small Iron Age hillfort. ${ }^{108}$ More generally, there is a long-held assumption that a considerable number of early medieval enclosed sites across Wales are masquerading as late prehistoric and are only currently identifiable through excavation and radiocarbon dating. A recent example of this is the exploratory excavation of a small promontory fort at Glanfraid, Llanfihangel Geneu'r Glyn, Ceredigion, previously assumed to be later prehistoric, which has revealed early medieval activity. Deposits in the bottom of the ditch were radiocarbon dated to the fifth or first half of the sixth centuries $\mathrm{AD}$ (with later iron smelting in the interior radiocarbon dated to the late seventh to late ninth centuries). ${ }^{109}$ Equally, at Castell Henllys, in north Pembrokeshire it has been suggested that the north-western entrance and the north-eastern rampart of the Iron Age promontory fort, as well as possibly the ditches, were refurbished in the late Roman or post-Roman period, but unfortunately, though

\footnotetext{
106 Ó Floinn 2001, 1-8.

107 Redknap, Portable Antiquities Scheme, GAT-242150.

108 Edwards 2007, P2-3; Archwilio, Dyfed Archaeological Trust, prn 2767.

109 Jones et al. 2017. The first sample was dated to cal AD 418-554 (UBA-30455), the second to cal AD 688-889 (UBA-24080) - both at 2 sigma. I am grateful to lestyn Jones for making this report available to me.
} 
the stratigraphy is supportive, there is neither radiocarbon nor artefactual dating to prove it. ${ }^{110}$ Nevertheless, it is very unlikely that we will be able to distinguish native sites from those of incomers since the artefactual assemblage, where there is one, need not be distinctively Irish and the population is likely to have become integrated relatively quickly. In south-west Wales the predominant Iron Age and native Roman period settlements are enclosed farmsteads, and in some instances these likewise have tantalising evidence of early medieval activity. For example, at Drim, one of a group of enclosed farmsteads at Llawhaden, Pembrokeshire, excavated in the 1980s, there was some evidence of early medieval activity in the form of a seventh- or eighth-century AD radiocarbon date from a slot possibly associated with a roundhouse and a stamped Type G2 copper-alloy penannular brooch. The excavator, Harold Mytum, was unsure whether two undated stone house platforms might be early medieval or later. ${ }^{111}$ Enclosed farmsteads such as this appear very similar to the raths and cashels of early medieval Ireland. There it has recently been argued that some settlement enclosures and multivallate ringforts may originate before AD 500. ${ }^{112}$ Therefore in this case we are seeing a similar pattern of enclosed homesteads on either side of the Irish Sea, presumably the products of similar agrarian societies rather than necessarily an Irish Sea identity.

Of course, the one settlement in Wales with an indisputably Irish identity is Llan-gors crannog, the construction of which is dendrochronologically dated to the 890 s. $^{113}$ Since this is the only known crannog in Wales, it should be seen as part of the reinvention by the rulers of ninth-century Brycheiniog of an Irish identity which was still visible in the landscape in the form of the earlier cluster of ogam stones found in this area.

\section{Conclusions}

\footnotetext{
110 Mytum 2013, 275-91. There is also a Roman settlement outside the enclosure to the north.

111 Williams and Mytum 1998, 62-4, fig. 45.

112 O'Sullivan et al. 2014, 64-6, fig. 3.7.

113 Campbell and Lane 1989; Redknap and Lane 1994; 1999; Redknap 1995, 65-7; 2004b.
} 
The fifth- to seventh-century inscribed stones indicate that there were three languages spoken in post-Roman Wales: Latin, Irish and Welsh and the formulae used also point to the increasing impact of Christianity, while the names and other words used can provide further valuable information, as can the archaeological contexts in which they were found. However, what I have tried to demonstrate is that, although these major differing identities are linguistically visible on the early inscribed stones, the construction of identities in this period was much more complex, as it is today. Furthermore, when we come to examine other aspects of the material evidence in early medieval Wales, it is often very difficult to understand these in terms of identities and, on the basis of our current knowledge, it is often easier to ask questions rather than to answer them. Concerning British (and Welsh) identities, the recognition of a past stretching back before the Roman conquest and the continuation and reinvention of that past does seem to be important both archaeologically and in the written sources. Equally, in attempting to understand the extent of the continuation and reinvention of Roman identities, it is essential to see the continuity of Christianity from the Roman period onwards as a very important aspect of this. It is also vital to see west Wales as a part of a wider Irish Sea zone which continued to have an impact on material evidence and identities long after the influx of Irish settlers in the immediate post-Roman period. Indeed, from the ninth century onwards north-west Wales in particular was drawn into a HibernoScandinavian orbit which is clearly visible in the archaeological evidence. ${ }^{114}$ Likewise, despite the barriers of Offa's and Wat's Dykes, discoveries of ornamental metalwork in the borderlands of the north-east and south-east begin to show evidence for the influence of English identities. ${ }^{115}$

\footnotetext{
114 Davies 1990, 51-60; Redknap 2004a; Edwards 2011, 82-7. For the recent discovery of a major mixed Hiberno-Scandinavian silver hoard from Llandwrog, Gwynedd, see Portable Antiquities Scheme: NMGW038729.

${ }^{115}$ Redknap 2007, 52-4. Again, there have been several additional Portable Antiquities Scheme finds.
} 


\section{Acknowledgments}

This paper was given as the 2017 O’Donnell lecture, originally endowed by Charles James O’Donnell (1850-1934). It was delivered in the universities of Bangor and Cardiff and University of Wales Trinity St David (Lampeter campus). It was also given at Harvard and a version of the part on Irish identities was first delivered at a conference in Liverpool University in July 2016. I am grateful for comments and suggestions made by members of the audience at all these events. My paper has also drawn on research for a project on 'Life in Early Medieval Wales' funded by the Leverhulme Trust and I am pleased to acknowledge their support.

Bibliography 
